\title{
Arctic-Alpine plants in Bulgarian mountains
}

\author{
Iva Apostlova, Hristo Pedashenko, Desislava Sopotlieva, Nikolay Velev, \\ Kiril Vassilev \& Tenyo Meshinev (*)
}

\begin{abstract}
Apostlova, I., Pedashenko, H., Sopotlieva, D., Velev, N., Vassilev, K. \& Meshine, T. Arctic-Alpine plants in Bulgarian mountains. Lazaroa 34: 55-63 (2013).

Bulgarian mountains are the southern distribution limit of several arctic-alpine species in Europe, many of them listed as threatened in the country. We assessed the diversity of arctic-alpine species in different mountain areas and selected the mountains with highest concentration of arctic-alpine species for field survey, sampling a total of 219 plots. The most frequently occurring species are Juncus trifidus, Poa alpina, Dryas octopetala, Bistorta vivipara, Omalotheca supina and Antennaria dioica. The frequency of these species increases with altitude and at northern aspect. Arctic-alpine plants take part in different vegetation classes, but are represented more frequently in Thlaspietea rotundifolii. The species tend to grow together, as a possible result of common functional characteristics and unified survival strategy. In 65\% of sampled locations more than one target species were observed. Dianthus microlepis and Primula minima demonstrate very high association with the arctic-alpine species.
\end{abstract}

Keywords: Balkans, glacial relics, mountain plants, southern Europe.

Resumen: Apostlova, I., Pedashenko, H., Sopotlieva, D., Velev, N., Vassilev, K. \& Meshine, T. Taxones ártico-alpinos en las montañas de Bulgaria. Lazaroa 34: 55-63 (2013).

Las montañas de Bulgaria representan el límte de distribución sur de varias especies ártico-alpinas en Europa, generalmente están consideradas en peligro. Se ha realizado un estudio sobre la diversidad ártico-alpina en distintas montañas con el objetivo de seleccionar aquellas con mayor concentración de dichas especies, muestreando un total de 219 parcelas. Las especies más frecuentes son Juncus trifidus, Poa alpina, Dryas octopetala, Bistorta vivipara, Omalotheca supina y Antennaria dioica, cuya frecuencia aumenta con la altitud y la exposición norte. En cuanto al habitat estos taxones aparecen en comunidades pertenecientes a distintas clases pero las más frecuentes son las de Thlaspietea rotundifolii. Además tienden a crecer juntas como resultado de una convergencia funcional y una similar estrategia de supervivencia, así en el $65 \%$ de las localidades muestreadas se observó más de una especie diana. Algunos taxones como Dianthus microlepis y Primula minima mostraron una alta asociación con las especies ártico-alpinas.

Palabras clave: Balcanes, especies relícticas, plantas de montañas, sur de Europa.

\section{INTRODUCTION}

Many cold-adapted species are naturally distributed in both Arctic and the mountain ranges of Europe. The species with current occurrence limited to the high latitudes of Arctic and high altitudes of mountain ranges of Central and Southern Europe, particularly in the Alps, are referred as "arctic-alpine" or "alpine-arctic" plants (OBERDORFER, 1994). Because of past, climate-related species shifts, the highest mountains of southern Europe represent an important refuge for many survived species, which are widely distributed in the northern Palaearctic (WILLIS, 1994; WILLIS \& Van Andel, 2004; Médail \& Diadema, 2009). The high mountains of the Balkan Peninsula are a good example of regional refuge for arctic-alpine species (ASSENOV, 2006; STEVANOVIĆ \& al., 2009). Some of these species are proven relics, based on macrofossil and pollen evidences (BIRKS \& WiLLIS, 2008). Others can be interpreted also as relics, survived in the Balkans during the cold stages of glaciations (StEVANOvić \& al., 2009; SCHMIDTT \& al., 2010).

* Institute of Biodiversity and Ecosystem Research. Bulgarian Academy of Sciences. Sofia 1113, Bulgaria. E-mail: iva.apostolova@gmail.com, hristo_pedashenko@yahoo.com, dsopotlieva@gmail.com, nikolay.velev@abv.bg, kiril5914@abv.bg, tmeshinev@gmail.com 
In recent years, arctic-alpine species have been the target of many studies, especially with regard to climate change (for overview, see e.g. THEURILlat \& Guisan, 2001; PAULi \& al., 2007). Other studies are focused on the genesis (STEHLIK, 2003; BIRKS, 2008; BHAGWAT \& WILLIS, 2008; OZENDA, 2009; HABEL \& al., 2010), species biology and ecology (BILlings \& MOONEY, 1968; TASCHLER \& NEUNER, 2004; IVERSEN \& al., 2009; LARCHER \& al., 2010), with special attention to their habitats and species relationships (HEEGAARD \& VANDVIK, 2004; POMPE \& al., 2010; FERNÁNDEZ \& MOLERO, 2011; GAVILÁn \& al., 2012).

However, there are many gaps in the knowledge about the ecology and distribution of these species in Bulgaria. Therefore, the aims of the present study are (1) to identify the arctic-alpine element in the Bulgarian mountains, and (2) to ascertain the distribution patterns of these species in respect to their ecology and phytosociological affinity.

\section{MATERIALS AND METHODS}

A list of arctic-alpine species occurring in Bulgaria was created following chorotype determination by AssYov \& PETROVA (2012) with corrections (of some boreal chorotypes) according to MEUSEL \& al. $(1965,1978)$ and OBERDORFER (1994). Species with contemporary occurrences also in Scandinavia, and especially in Norway were objects of field observation. Data about species distribution in the country were extracted from literature (STOJANOFF, 1940; DelipaVlov \& al., 2003; Assyov \& Petrova, 2012).

Following the information about known occurrences of these species as well as our previous experience, we focused on the highest mountains in Bulgaria - Rila (2925 m asl), Pirin (2914 m asl) and Stara Planina (2376 m asl) (Figure 1). Climate of the study areas is characterised by relatively high rainfall (1000 $\mathrm{mm}$ annual precipitation) and low temperatures (mean January $-10.9^{\circ} \mathrm{C}$, July $5^{\circ} \mathrm{C}$ ). Snow cover lasts $190-200$ days (MAATEVA, 2002). The study areas represent typical alpine surface of rocky slopes, mountain cliffs, and high mountain shrubs and pastures. They were chosen as to comprise different conditions of exposure, inclination and micro-habitat characteristics. The study area in Rila was $6.65 \mathrm{~km}^{2}$, in Pirin $4.12 \mathrm{~km}^{2}$ and in Stara Planina $13.75 \mathrm{~km}^{2}$. The localities were systematically sampled by $16 \mathrm{~m} 2$ plots, following the Braun-Blanquet approach

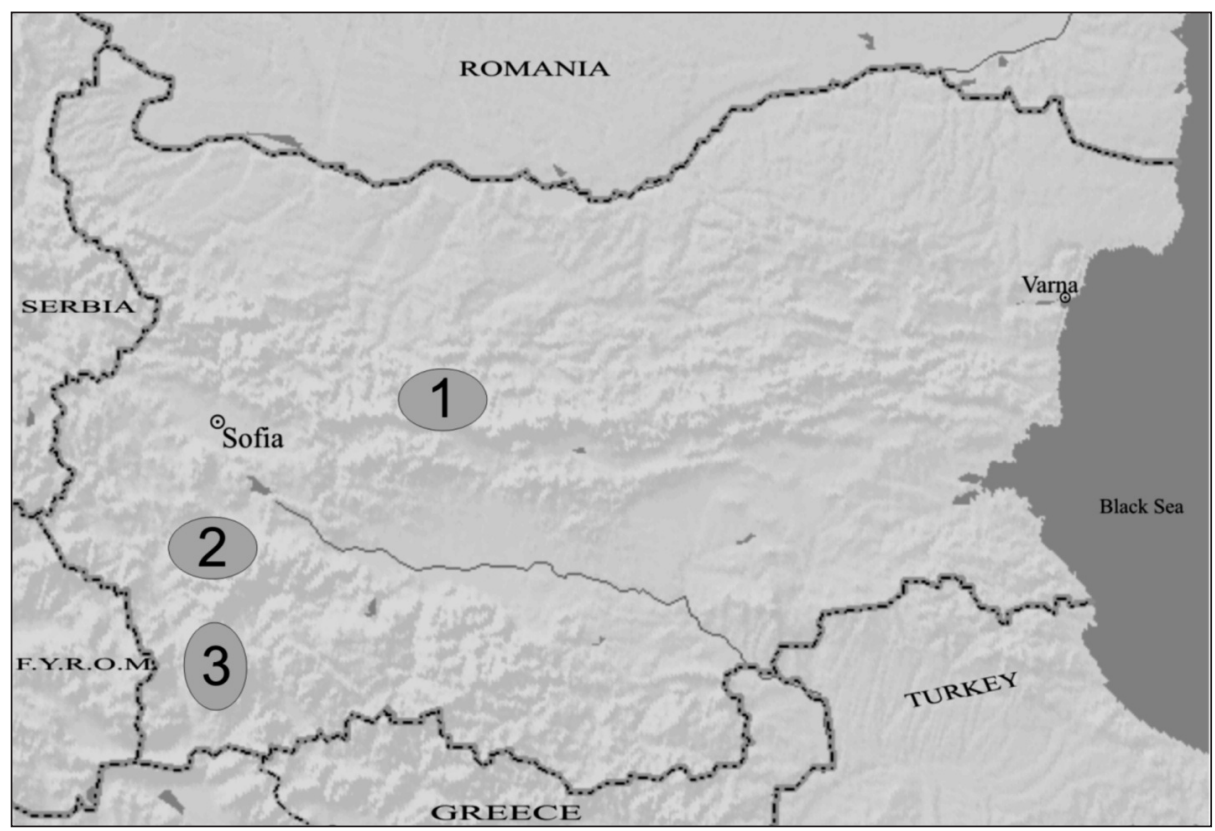

Figure 1. - Study regions: 1, Stara Planina Mountains; 2, Rila Mountains; 3, Pirin Mountains. 
(WeSthofF \& VAN DER MAAREL, 1978). We sampled a total of 219 plots. Distinct locations for the same species were considered those, outlying at least $50 \mathrm{~m}$. In each plot we collected latitude/longitude, altitude and aspect using GPS (Garmin Etrex) and slope (inclinometer). Field data was collected during 2009 and 2010.

The relationship between the number of plants, selected for observation and the vegetation cover of accompanying plants in the sample plots, was tested by simple linear regression. Spearman's rank correlation coefficient was calculated in order to test the dependence between, number of species and the cover of accompanying plants. The analyses were performed by Statistica 9.0 (Statsoft Inc).

\section{RESULTS}

The list of arctic-alpine plant species represented in Bulgaria includes 38 taxa (Table 1). All species are distributed exceptionally in the mountains at the altitudinal range between 800 and $2900 \mathrm{~m}$. The frequency of arctic-alpine plants increases at higher altitudes (Figure 2). Different number of species was registered across mountain systems (Figure 3). The highest number of arctic-alpine species is located in Rila Mt., followed by Pirin and Stara Planina Mts. Their spatial distribution is uneven and principally reflects their rarity. We registered 16 species from the list within the study sites. The most frequently occurring were Juncus trifidus, Poa al-

Table 1

List of arctic-alpine plants in Bulgaria

(*CR-critically endangered, EN-endangered, VU-vulnerable, NT-near threatened, BDA-biodiversity act; **Data on phenology is extracted from cited local flora)

\begin{tabular}{|c|c|c|c|c|c|c|}
\hline \multirow[t]{2}{*}{$\begin{array}{c}\text { Conservation } \\
\text { status* }\end{array}$} & \multirow[t]{2}{*}{ Species } & \multicolumn{2}{|c|}{$\begin{array}{l}\text { Distribution } \\
\text { range in } \\
\text { altitude }(\mathrm{m})\end{array}$} & \multirow[t]{2}{*}{$\begin{array}{c}\text { Occupancy in vegetation } \\
\text { classes }\end{array}$} & \multirow{2}{*}{$\begin{array}{c}\text { Start } \\
\text { flowering } \\
\text { (month) } \\
* *\end{array}$} & \multirow{2}{*}{$\begin{array}{c}\text { Fowering } \\
\text { duration } \\
\text { (months) } \\
* *\end{array}$} \\
\hline & & Low & High & & & \\
\hline- & Arabis alpina $\mathrm{L}$. & 1000 & 2900 & Thlaspietea rotundifolii & IV & 5 \\
\hline- & $\begin{array}{l}\text { Antennaria dioica }(\mathrm{L} .) \\
\text { Gaertner }\end{array}$ & 1700 & 2900 & $\begin{array}{l}\text { Salicetea herbaceae, } \\
\text { Juncetea trifidi, } \\
\text { Thlaspietea rotundifolii }\end{array}$ & V & 4 \\
\hline- & Aster alpinus L. & 1300 & 2900 & $\begin{array}{c}\text { Carici rupestris-Kobresietea } \\
\text { bellardii, Asplenietea trichomanis, } \\
\text { Thlaspietea rotundifolii }\end{array}$ & VI & 3 \\
\hline NT & Bartsia alpina L. & 2100 & 2600 & $\begin{array}{l}\text { Salicetea herbaceae, } \\
\text { Thlaspietea rotundifolii }\end{array}$ & $\begin{array}{l}\text { VII } \\
\text { VI }\end{array}$ & $\begin{array}{l}2 \\
3\end{array}$ \\
\hline- & $\begin{array}{l}\text { Bistorta vivipara (L.) S. F. } \\
\text { Gray }\end{array}$ & 1600 & 2750 & Juncetea trifidi & & \\
\hline- & Carex atrata $\mathrm{L}$. & 2000 & 2600 & $\begin{array}{l}\text { Asplenietea trichomanis, } \\
\text { Thlaspietea rotundifolii }\end{array}$ & VII & 2 \\
\hline- & Cerastium alpinum $\mathrm{L}$. & 1300 & 1500 & Thlaspietea rotundifolii & VII & 2 \\
\hline- & $\begin{array}{l}\text { Cerastium cerastoides }(\mathrm{L} .) \\
\text { Britton }\end{array}$ & 2000 & 2900 & $\begin{array}{c}\text { Salicetea herbaceae, } \\
\text { Scheuchzerio-Caricetea nigrae }\end{array}$ & VI & 3 \\
\hline VU, BDA & $\begin{array}{l}\text { Diphasiastrum alpinum (L.) J. } \\
\text { Holub }\end{array}$ & 1700 & 2100 & Juncetea trifidi & VII & 3 \\
\hline- & Dryas octopetala L. & 2000 & 2900 & $\begin{array}{c}\text { Carici rupestris-Kobresietea } \\
\text { bellardii, Juncetea trifidi, } \\
\text { Thlaspietea rotundifolii }\end{array}$ & VI & 3 \\
\hline $\mathrm{EN}, \mathrm{BDA}$ & $\begin{array}{l}\text { Empetrum nigrum L. subsp. } \\
\text { hermaphroditum (Hagerup) } \\
\text { Böscher }\end{array}$ & 2200 & 2700 & Thlaspietea rotundifolii & VI & 2 \\
\hline- & $\begin{array}{l}\text { Epilobium anagallidifolium } \\
\text { Lam. }\end{array}$ & 800 & 2500 & $\begin{array}{c}\text { Salicetea herbaceae, } \\
\text { Scheuchzerio-Caricetea nigrae, } \\
\text { Montio-Cardaminetea }\end{array}$ & VII & 3 \\
\hline
\end{tabular}




\begin{tabular}{|c|c|c|c|c|c|c|}
\hline $\begin{array}{c}\text { Conservatior } \\
\text { status* }\end{array}$ & Species & $\begin{array}{l}\text { Distri } \\
\text { ran } \\
\text { altitu } \\
\text { Low }\end{array}$ & $\begin{array}{l}\text { bution } \\
\text { ge in } \\
\text { de }(\mathrm{m}) \\
\text { High }\end{array}$ & $\begin{array}{c}\text { Occupancy in vegetation } \\
\text { classes }\end{array}$ & $\begin{array}{l}\text { Start } \\
\text { flowering } \\
\text { (month) } \\
\quad * *\end{array}$ & $\begin{array}{l}\text { Fowering } \\
\text { duration } \\
\text { (months) } \\
* *\end{array}$ \\
\hline- & Festuca airoides Lam. & 1400 & 1800 & Juncetea trifidi & VI & 2 \\
\hline EN & Gentiana nivalis L. & 1800 & 2900 & $\begin{array}{l}\text { Carici rupestris-Kobresietea } \\
\text { bellardii, Juncetea trifidi }\end{array}$ & VII & 2 \\
\hline- & Juncus trifidus L. & 2000 & 2900 & $\begin{array}{c}\text { Salicetea herbaceae, Carici } \\
\text { rupestris-Kobresietea bellardii, } \\
\text { Juncetea trifidi, Thlaspietea } \\
\text { rotundifolii }\end{array}$ & VII & 2 \\
\hline $\mathrm{CR}, \mathrm{BDA}$ & Juncus triglumis L. & 2000 & 2500 & Scheuchzerio-Caricetea nigrae & VII & 2 \\
\hline $\mathrm{EN}, \mathrm{BDA}$ & $\begin{array}{l}\text { Kobresia myosuroides (All.) } \\
\text { W. Koch }\end{array}$ & 2100 & 2700 & $\begin{array}{c}\text { Carici rupestris-Kobresietea } \\
\text { bellardii, Thlaspietea rotundifolii }\end{array}$ & $i^{\mathrm{VI}}$ & 3 \\
\hline $\mathrm{EN}, \mathrm{BDA}$ & Lloydia serotina (L.) Reichenb. & 900 & 2900 & $\begin{array}{c}\text { Carici rupestris-Kobresietea } \\
\text { bellardii, Thlaspietea rotundifolii }\end{array}$ & VII & 2 \\
\hline- & $\begin{array}{l}\text { Omalotheca norvegica (Gunn.) } \\
\text { Schultz-Bip. et F. Schul. }\end{array}$ & 900 & 1000 & $\begin{array}{l}\text { Asplenietea trichomanis, } \\
\text { Thlaspietea rotundifolii }\end{array}$ & VI & 4 \\
\hline- & Omalotheca supina (L.) DC. & 2000 & 2900 & $\begin{array}{c}\text { Salicetea herbaceae, Juncetea } \\
\text { trifidi, Asplenietea trichomanis, } \\
\text { Thlaspietea rotundifolii }\end{array}$ & VI & 4 \\
\hline- & Oxyria digyna (L.) Hill. & 1800 & 2800 & $\begin{array}{l}\text { Salicetea herbaceae, } \\
\text { Thlaspietea rotundifolii }\end{array}$ & VII & 2 \\
\hline- & Oxytropis campestris (L.) DC. & 2500 & 2500 & $\begin{array}{c}\text { Carici rupestris-Kobresietea } \\
\text { bellardii, Thlaspietea rotundifolii }\end{array}$ & VII & 3 \\
\hline EN & Pedicularis oederi Vahl & 2000 & 2900 & $\begin{array}{c}\text { Juncetea trifidi, Thlaspietea } \\
\text { rotundifolii }\end{array}$ & VI & 2 \\
\hline- & Pedicularis verticillata $\mathrm{L}$. & 1000 & 2900 & $\begin{array}{c}\text { Juncetea trifidi, Thlaspietea } \\
\text { rotundifolii }\end{array}$ & VII & 2 \\
\hline- & Phleum alpinum $\mathrm{L}$. & 1600 & 2500 & Juncetea trifidi & VIII & 2 \\
\hline- & Poa alpina $\mathrm{L}$. & 1500 & 2000 & $\begin{array}{c}\text { Juncetea trifidi, Thlaspietea } \\
\text { rotundifolii }\end{array}$ & VI & 2 \\
\hline- & Poa laxa Haenke & 2000 & 2900 & $\begin{array}{c}\text { Juncetea trifidi, Thlaspietea } \\
\text { rotundifolii }\end{array}$ & VI & 2 \\
\hline- & $\begin{array}{l}\text { Potentilla crantzii (Crantz) } \\
\text { Beck ex Fritsch }\end{array}$ & 1800 & 2700 & Juncetea trifidi & VI & 4 \\
\hline $\mathrm{CR}, \mathrm{BDA}$ & Rhodiola rosea $\mathrm{L}$. & 1800 & 2600 & Thlaspietea rotundifolii & VI & 3 \\
\hline- & Sagina saginoides (L.) Karsten & 1500 & 2900 & $\begin{array}{l}\text { Salicetea herbaceae, } \\
\text { Juncetea trifidi }\end{array}$ & VI & 3 \\
\hline- & Salix herbacea L. & 2400 & 2900 & Salicetea herbaceae & VI & 2 \\
\hline- & Salix reticulata $\mathrm{L}$. & 2500 & 2900 & Salicetea herbaceae & VI & 2 \\
\hline VU & Saxifraga oppositifolia L. & 2300 & 2900 & Asplenietea trichomanis & VII & 2 \\
\hline- & Saxifraga paniculata Mill. & 800 & 2500 & $\begin{array}{c}\text { Carici rupestris-Kobresietea } \\
\text { bellardii, Asplenietea } \\
\text { trichomanis }\end{array}$ & V & 2 \\
\hline- & Saxifraga stellaris $\mathrm{L}$. & 1800 & 2500 & $\begin{array}{c}\text { Scheuchzeri-Caricetea nigrae, } \\
\text { Montio-Cardaminetea }\end{array}$ & VII & 3 \\
\hline- & $\begin{array}{l}\text { Selaginella selaginoides (L.) } \\
\text { Link }\end{array}$ & 2200 & 2800 & $\begin{array}{c}\text { Juncetea trifidi, Thlaspietea } \\
\text { rotundifolii }\end{array}$ & VII & 3 \\
\hline EN & Sibbaldia procumbens L. & 2000 & 2800 & $\begin{array}{l}\text { Salicetea herbaceae, } \\
\text { Asplenietea trichomanis, } \\
\text { Thlaspietea rotundifolii }\end{array}$ & VI & 3 \\
\hline- & Silene acaulis (L.) Jacq. & 2200 & 2900 & $\begin{array}{l}\text { Juncetea trifidi, } \\
\text { Thlaspietea rotundifolii }\end{array}$ & VII & 2 \\
\hline
\end{tabular}




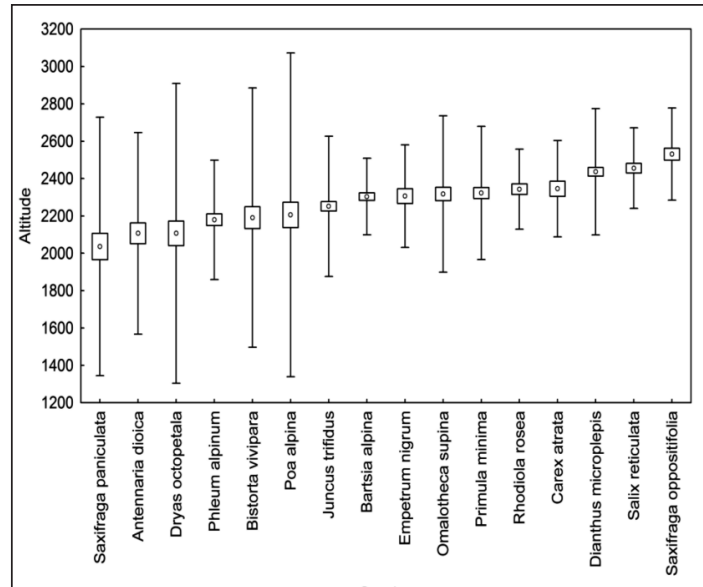

Figure 2. - Sampled altitudinal range of the arctic-alpine species in Bulgaria. (points represent means, boxes 25$75 \%$ range and whiskers $\min / \max$ values).

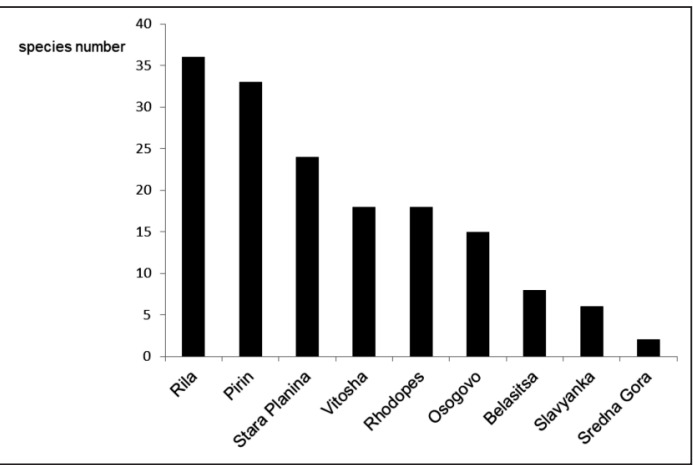

Figure 3. - Distribution of arctic-alpine plants over Bulgarian mountains.

pina, Dryas octopetala, Bistorta vivipara, Antennaria dioica and Omalotheca supina (Figure 4).

The highest number $(42.3 \%)$ of localities were facing north, regardless of the fact that study areas share all possible aspects. On southern slopes were placed $33.2 \%$ of the localities, while these facing east $(17.3 \%)$ and west $(3.7 \%)$ were less presented. Bistorta vivipara, Carex atrata, Empetrum nigrum and Oxyria digyna were registered only on north facing slopes. None of the observed species was discovered on southern slopes only. Detailed species distribution over the main directions is shown on Figure 5. The slope inclination varies between 3 and 46 degrees, most often it is 23 .

All listed species have short growing period and are adapted for flowering within 2-3 months

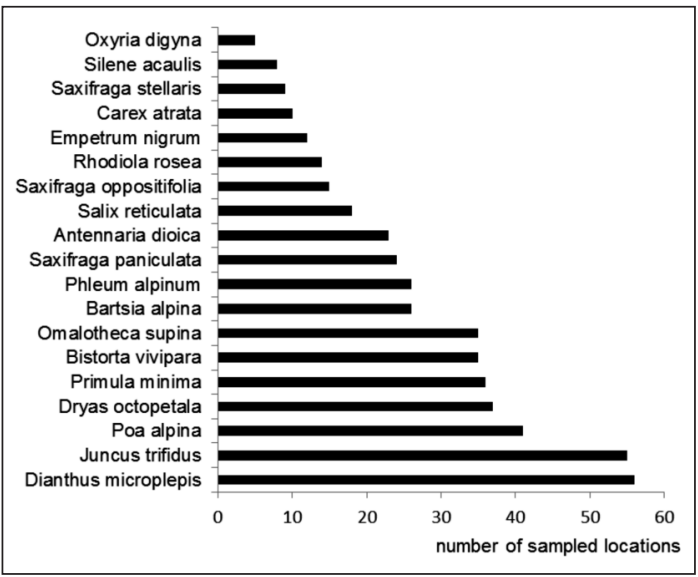

Figure 4. - Species frequency in sampled locations.

(Table 1). Seventy percent of listed arctic-alpine plants develop rhizomatous root system, which provides resources for fast growing and seed production in limited vegetation period.

In 77 plots (35.2\%) there was only one arcticalpine species, while in 142 plots $(64.8 \%)$ more than one species were registered. High association with arctic-alpine plants exhibit Balkan endemic Dianthus microlepis Boiss. and Alpic-CarpathicBalkanic Primula minima L. These species were

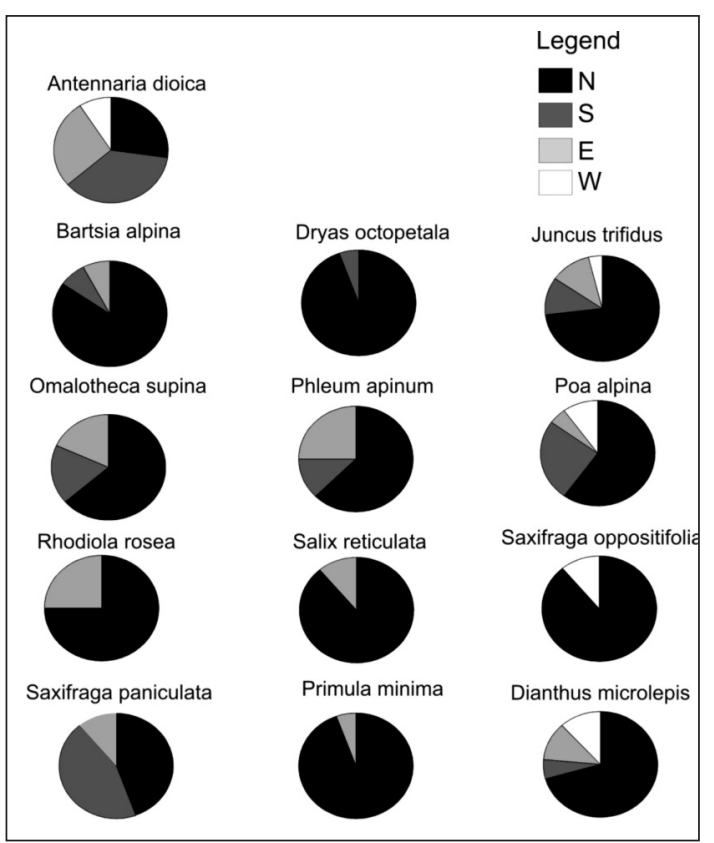

Figure 5.- Species frequency at different exposures. 


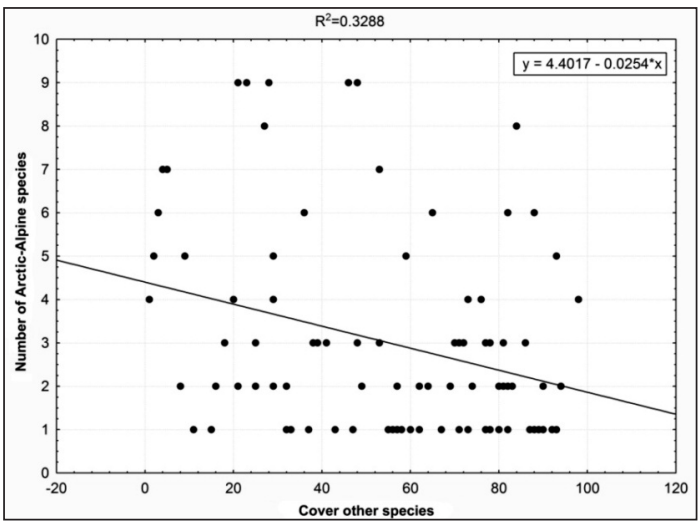

Figure 6. - Correlation between number of studied species and cover of accompanying plants.

registered in $25.6 \%$ and $16.4 \%$ of all sampled plots respectively. Endemics Primula deorum Velen and Geum bulgaricum Pančić, were observed together with other listed species in Rila Mt., while Papaver degenii (Urum. et Javorka) Kuzmanov was sampled locally in Pirin Mt.

Total vegetation cover in the sampled plots varies between 15 and $98 \%$. The median of these values is $85 \%$. In almost all plots there was moss layer covered from $1 \%$ to $40 \%$ of the plot. Bare rocks also were presented in some plots reaching up to $8 \%$ of the area. We established that besides Dianthus microlepis and Primula minima other plants, which accompany arctic-alpine species share a relatively small part of the total species cover in the vegetation. In case of high number of arctic-alpine plants in a sample plot, the group of other co-occurring plants has lower cover value. In the sample plots with highest abundance of arctic-alpine plants (7-10 species) the cover of accompanying species varies between $1 \%$ and $48 \%$. Figure 6 shows the relationship between the cover of accompanying plants and the number of arctic-alpine species in studied plots.

\section{DISCUSSION}

GENERAL TRENDS IN DISTRIBUTION OF ARCTICALPINE PLANTS IN BULGARIAN MOUNTAINS

Balkan Peninsula is known as one of the refuges for plant survival during glaciations (BIRKS
\& WILlis, 2008). At this time both Rila and Pirin Mts were covered by ice, while Stara Planina Mt. was considered not permanently glaciated (VLASKOV, 2002). It is believed that during ice persistence many species from high latitudes have migrated southward and survived in the southern Europe, particularly in Balkans (OzENDA, 2009). Palynological data proves that during late glacial period steppe-mountain vegetation has been developed in high Balkan mountains (STEFANOVA \& AmMan, 2003; TONKov \& al., 2006). After ice withdrawal, the species demanding higher humidity and cold resistant started to climb up mountain slopes. This process was simultaneously accompanied by other local species, which certainly had more thermophilous nature, and thus influenced the ascent of current arctic-alpine plants. During following periods steppe-mountain vegetation was partly replaced by pines and temperate deciduous trees. In mountains of lower altitude such as Sredna gora Mt. (highest peak 1604 m) forest vegetation persist to date and provides very few suitable habitats for arctic-alpine plants. Eroded places and secondary grasslands there host only Antennaria dioica and Phleum alpinum.

Present distribution of arctic-alpine species in Bulgarian mountains reflects the migration routes and available space. Major routes are illustrated by SteVANOvić \& al. (2009). The number of species for Vitosha Mt. and the Rhodopes is the same, but Vitosha has much smaller territory, that ranks it up as mountain area with relatively high concentration of arctic-alpine plants. Its close proximity to Rila and similarity of rock types gives reason to assume existence of long lasting historical migration routes between them for many species. The Rhodopes are characterized by huge coniferous forests, much more similar to Boreal region than Arctic.

Our findings demonstrate that the studied plants establish and survive in high altitudes, at wind exposed northern slopes, as in other southern Europe mountains. The overall vegetation cover is low there and plenty of open space is available. Many authors (e.g. TASHLER \& NEUNER, 2004; LARCHER \& al., 2010; HABEL \& al., 2010) suppose that the high ability to resist severe winds and low temperatures together with weak competition ability are 
the major driving mechanisms for arctic-alpine species occurrence. Observed species occupy the area above the timberline (with few exceptions as Diphasiastrum alpinum, Epilobium anagallidifolium, Omalotheca norvegica, Saxifraga paniculata, Phleum alpinum, Selaginella selaginoides and Antennaria dioica). This observation is in conformity with the overall arctic-alpine plant distribution at the southern range, reported also by other authors (TOMASELLI, 1991; BRUUN \& al., 2006; GUTIÉRREZ \& GAVILÁN, 2010; VITTOZ \& al., 2010).

Most of the studied species develop in rock and scree habitats. Natural or human induced disturbances provide additional space for plants demanding openings, such as Antennaria dioica and Omalotheca supina which are closely tied to patches, disturbed by erosion. On plane or slightly inclined terrains the surface is covered by soil of up to $20 \mathrm{~cm}$ depth and provides opportunity for development of tussock grasses as for example Nardus stricta, Sesleria comosa, Sesleria latifolia and Festuca nigrescens. The only arctic-alpine species registered there were Phleum alpinum and Bistorta vivipara. Considering the statement of GRABHERR (1989) that the "alpine grasslands can be defined as build of one or few keystone species and a couple of associates which are weak competitors", we could perceive as "keystone species" among listed plants only Juncus trifidus.

It is noteworthy that arctic-alpine species grow closely to each other and this is why they were often registered together in the sample plots. Such species association is justified by common ecological requirements (BILLINGS \& MoONEY, 1968; IVERSEN \& al., 2009; LARCHER \& al., 2010). Juncus trifidus, Bistorta vivipara, Poa alpina, Dryas octopetala, Bartsia alpina and Omalotheca supina manifest the highest association ability. Dianthus microlepis and Primula minima should be mentioned as strong companions to the arcticalpine plants in Bulgarian mountains.

Despite the fact that arctic-alpine species occupy small number of habitats, they take part in different syntaxa. According to our current knowledge (HoRvat \& al., 1937; SiMON, 1958; MUCINA \& al., 1990; ROUSSAKOVA, 2000; HÁJEK \& al., 2008), 7 classes should be mentioned as characteristic for the arctic-alpine plants in Bulgaria (see Table 1). Salicetea herbaceae is presented in Rila and Pirin Mts only. Carici rupestris-Kobresietea bellardii is registered only in Rila. Communities of Juncetea trifidi, occupying the highest alpine zone in Rila, Pirin, Stara Planina, Vitosha, Rhodope and Osogovo are broadly distributed. Vegetation tied to rocks and scree habitats is included in Asplenietea trichomanis and Thlaspietea rotundifolii, reported so far for Rila and Pirin, but our recent, not published data show their distribution in other mountains too. The alpine scree communities are extremely rich in rare and endemic species. Scheuchzerio-Caricetea nigrae and Montio-Cardaminetea are presented in all mountains but, occupy very limited areas.

\section{IMPLICATIONS FOR CONSERVATION}

We consider the competition between arctic-alpine plants and expanding populations of shrubs and tussock grasses extremely important. Our study allows us to conclude that the presence of open spaces is an important condition for the existence of the observed species. The limited presence of grasses there is perhaps conditioned by the shallow and unstable soil substrate and strong winds. However, this factor does not influence shrub expansion (ERSCHBAAMER \& al., 2009). Juniperus sibirica manifests intensive population increase as a result of deceased or abandoned grazing (VELEV \& Apostolova, 2008). By analogy, to a lesser extent same is true for Pinus mugo. Presence of Juniperus sibirica was registered in the half of the sample plots, while Pinus mugo was registered only in four locations. A similar concern for shrub invasion in other European mountain systems was stated also by other researchers (CHOLER \& al., 2001; Sснӧв \& al., 2009).

The anthropogenic impact might be evaluated as low for the whole group of arctic-alpine species due to their relatively difficult accessibility. However, their small populations and significant fragmentation, together with the increasing touristic activities in the mountains are factors that should be considered as threatening. According to the National Red List of vascular plants (PETROvA \& VLADIMIROV, 2009) Juncus triglumis and Rhodiola rosea are evaluated as critically endangered, 
because the first is known from a single location while the second is subject to active collection as medicinal plant. Another 6 species (see Table 1) are endangered. Species that are represented in few localities or by scarce populations are listed in the National Biodiversity Act (2008) as well.

It should be mentioned that all arctic-alpine species somehow prefer wet environment. Actively launched idea for climate warming and xerophytisation puts in jeopardy these species as they may lose their contemporary habitats. Following this scenario, these species will not outlive further warming, because there are no more appropriate upward territories for migration (they already occupy the top of the mountains) which is the case in many south- European regions (BIRKS, 2008; PAROLO \& Rossi, 2008).

\section{ACKNOWLEDGEMENTS}

This work was financially supported by the EEA Grants, Project BG0034-GAE-00100-E-V1 - EEA FM. We thank the two reviewers for all suggestions that helped us to improve earlier version of the manuscript.

\section{REFERENCES}

Assenov, A. -2006 - Biogeography of Bulgaria - An-Di Andrian Tasev, Sofia, 543pp. [in Bulgarian].

Assyov, B.\& Petrova, A. (eds) - 2012-Conspectus of the Bulgarian Vascular Flora. Distribution maps and floristic elements, 4th ed. - BBF, Sofia. 489 pp.

Bhagwat, S. \& Willis, K. - 2008- Species persistence in northerly glacial refugia of Europe: a matter of chance or biogeographical traits? - J. Biogeogr. 35: 464-482.

Billings, W.D. \& Mooney, H. A. - 1968 - The ecology of arctic and alpine plants - Biological reviews 43(4): 481-529.

Birks, H. -2008 - The Late-Quaternary history of arctic and alpine plants - Plant Ecol. Div. 1(2): 135-146.

Birks, H. \& Willis, K. - 2008- Alpines, trees and refugia in Europe - Plant Ecol. \& Div. 1(2): 147-160.

Bruun, H., Moen, J., Virtanen, R., Grytnes, J.A., Oksanen, L. \& Angerbjörn, A. -2006- Effects of altitude and topography on species richness of vascular plants, bryophytes and lichens in alpine communities $-\mathrm{J}$. Veg. Sci. 17(1): 37-46.

Choler, P., Michalet, R. \& Callaway, R. -2001 - Facilitation and competition on gradients in alpine plant communities - Ecology 82(12): 3295-3308.

Delipavlov, D. \& Cheshmedjiev, I. - 2003 - Determination key for Bulgarian plants - Acad. Publishing, Plovdiv. 591pp. [in Bulgarian]

Fernández Calzado, M.R. \& Molero Mesa, J. - 2011 - The cartography of vegetation in the cryoromediterranean belt of Sierra Nevada: a tool for biodiversity conservation - Lazaroa 32: 101-115

Grabherr, G. - 1989- On community structure of high alpine grasslands - Vegetatio 3(1-2): 223-227.

Gavilán, R.G., Díez-Monsalve, E., Izquierdo, J.L., Gutiérrez-Girón, A., Fernández-González, F. \& SánchezMata, D. -2012 - An approach towards the knowledge of Iberian high-mountain calcareous grasslands - Lazaroa 33: 43-50.

Gutiérrez, A. \& Gavilán, R.G. -2010 - Spatial patterns and interspecific relations analysis help to better unders- tand species distribution patterns in a Mediterranean high mountain grassland - Plant Ecol. 210: 137-151.

Habel, J., Drees, C., Schmidtt, T. \& Assmann, T. - 2010Review. Refugial areas and postglacial colonizations in the Western Palearctic - In: Habel, J.C. \& Assmann, T. (Eds.). Relic species: Phylogeography and conservation biology. Pp. 189-197. Springer-Verlag, Berlin, Heidelberg.

Hajek, M., Hajkova, P., \& Apostolova, I. -2008 - New plant associations from Bulgarian mires - Phytol. Balcan. 14(3): 377-399.

Heegaard, E. \& Vandvik, V. -2004- Climate change affects the outcome of competitive interactions - an application of principal response curves - Oecologia 139: 459-466

Horvat, I., Pawlowski, B. \& Walas, L. - 1937 - Phytosociologische Studien über die Hochgebirgvegetation der Rila Planina in Bulgarien - Bull. Int. Acad. Pol. Cl. Sci. Math. Ser. B 1, Bot.: 159-189.

Iversen, M., Bráthen, K., Yoccoz, N. \& Ims, R. -2009Predictors of plant phenology in a diverse high-latitude alpine landscape: growth forms and topography J.Veg. Sci. 20(5): 903-915.

Larcher, W., Kainmüller, C. \& Wagner, J. -2010 - Survival types of high mountain plants under extreme temperatures - Flora 205: 3-18.

Mateeva, Z. - 2002-Precipitation and snow cover - In: Kopralev, I. (Ed.). Geography of Bulgaria. Pp.152-154. ForCom Publishing, Sofia.

Médail, F. \& Diadema, K. -2009-Glacial refugia influence plant diversity patterns in the Mediterranean Basin - J. Biogeogr. 36:1333-1345.

Meusel, H., Jäger, E. \& Weinert, E. - 1965-Vergleichende Chorologie der Zentraleropäischen Flora. 1. Karten Veb Gustav Fischer Verlag, Jena.

Meusel, H., Jäger, E., Rauschert, S. \& Weinert, E. -1978Vergleichende Chorologie der Zentraleropäischen Flora. 2. Karten - Veb Gustav Fischer Verlag, Jena. 
Mucina, L., Valachovič, M., Jarolímek, I., Šeffer, J., Kubínska, A. \& Pišút, I. - 1990-The vegetation of rock fissures, screes and snow beds in the Pirin Mountains (Bulgaria) - Stud. Geobot. 10: 15-58.

Oberdorfer, E. - 1994- Phlanzensociologische Exkursionsflora - Verlag Eugen Ulmer, Stuttgard.

Ozenda, P. - 2009- On the genesis of the plant population in the Alps: New or critical aspects - Compt. Rend. Biol. 332: 1092-1103.

Parolo, G. \& Rossi, G. -2008- Upward migration of vascular plants following a climate warming trend in the Alps - Basic Appl. Ecol. 9(2): 100-107.

Pauli, H., Gottfried, M., Reiter, K., Klettner, C. \& Grabherr, G. - 2007- Signals of range expansions and contractions of vascular plants in the high Alps: Observations (1994-2004) at the GLORIA master site Schrankogel, Tyrol, Austria - Global Change Biol. 13: 147-156.

Petrova, A. \& Vladimirov, V. (Eds.) - 2009- Red list of Bulgarian vascular plants - Phytol. Balcan. 15(1): 63-94.

Pompe, S., Hanspach, J., Badeck, F-W., Klotz, S., Bruelheide, H. \& Ingolf, K. -2010 - Investigating habitatspecific plant species pools under climate change Basic .Appl. Ecol. 11(7): 603-611.

Roussakova, V. - 2000 - Vegetation alpine and sous alpine superior de la montagne de Rila (Bulgarie) - BraunBlanquetia 25: 3-132.

Schmidtt, T., Muster, Ch. \& Schönswetter, P. -2010- Are disjunct Alpine and Arctic-Alpine animal and plant species in the Western Palearctic really "relics of a cold past”? - In: Habel, J.C., Assmann, T. (Eds.). Relic species: Phylogeography and conservation biology. Pp. 239252. Springer-Verlag, Berlin Heidelberg.

Simon, T. - 1958 - Über die alpine Pflanzengesellschaften des Pirin Gebirges - Acta Bot. Acad. Sci. Hung. 4(12): 159-189.

Stefanova, I. \& Ammann, B. -2003 - Lateglacial and Holocene vegetation belts in the Pirin Mountains (southwestern Bulgaria) - The Holocene 13(1): 97-107.

Stehlik, I. - 2003 - Resistance or emigration? Response of alpine plants to the ice ages - Taxon 52(3): 499-510.
Stevanović, V., Vukojičić, S., Sinžar-Sekulić, J., Lazarević, M., Tomović, G. \& Tan, K. -2009- Distribution and diversity of Arctic-Alpine species in the Balkans Plant Syst. Evol. 283: 219-235.

Stojanoff, N. - 1940 - Zur Frage über die Herkunft des arctischen Elements in der Flora der Balkanländer Ann. Univ. Sofia 36(3), Sci. Nat. 1939/1940: 195-250.

Taschler, D. \& Neuner, G. - 2004- Summer frost resistance and freezing patterns measured in situ in leaves of major alpine plant growth forms in relation to their upper distribution boundary - Plant Cell Environ. 27: 737 746.

Theurillat, J.P. \& Guisan, A. - 2001 - Potential impact of climate change on vegetation in the European Alps: a review - Clim. Change 50: 77-109.

Tomaselli, M. - 1991 - The snow-bed vegetation in the Northern Apennines — Vegetatio 94: 177-189.

Tonkov, S., Possnert, G. \& Bozilova, E. -2006- The lateglacial vegetation and radiocarbon dating of Lake Trilistnika, Rila Mountains (Bulgaria) - Veg. Hist. Archaeobot. 16: 15-22.

Velev, N. \& Apostolova, I. - 2008 - Successional changes of Nardus stricta communities in the Central Balkan Range (Bulgaria) - Phytol. Balcan. 14(1): 65-74.

Vittoz, P., Camenisch, M., Mayor, R., Miserere, L., Mathias, V. \& Theurillat, J-P. - 2010 - Subalpine-nival gradient of species richness for vascular plants, bryophytes and lichens in the Swiss Inner Alps - Bot. Helv. 120(2): 139-149.

Vlaskov, V. - 2002-Glacial and periglacial morphosculpture - In: Kopralev, I. (Ed.). Geography of Bulgaria, BAS. Pp. 60-63. For. Com. Press, Sofia [in Bulgarian].

Westhoff, V., van der Maarel, E. - 1978-The Baun-Blanquet approach - In: Whittaker, R.H. (Ed.). Classification of plant communities. Pp. 287-399. Junk, the Hague.

Willis, K. - 1994- The vegetation history of the Balkans — Quat. Sci. Rev. 13: 769-788.

Willis, K. \& van Andel, T. - 2004- Trees or no trees? The environment of Central and Eastern Europe during the last Glaciation - Quat. Sci. Rev. 23: 2369-2387. 